\title{
多変量解析を用いた石灰岩帯水層における 地下水水質の統計的分類 \\ MULTIVARIATE STATISTICAL CHARACTERIZATION OF GROUNDWATER QUALITY IN LIMESTONE AQUIFER, OKINAWA, JAPAN
}

\author{
安元純 聖川健斗 仲栄真史哉 砥綿泰弘 中野拓治 \\ Jun YASUMOTO $^{1}$, Kento HIJIKAWA ${ }^{2}$, Fumiya NAKAEMA ${ }^{2}$, Yasuhiro TOWATA ${ }^{3}$ \\ and Takuji NAKANO 4 \\ 1正会員 農博 琉球大学 農学部 地域農業工学科（广903-0213 沖縄県中頭郡西原町字千原1番地） \\ 2非会員 琉球大学 農学部 地域農業工学科 （同上） \\ 3 非会員 野村貿易大阪本社（广541-8542 大阪市中央区安土町1丁目7番3号) \\ 4正会員 工博 琉球大学 農学部 地域農業工学科（广903-0213 沖縄県中頭郡西原町字千原1番地）
}

\begin{abstract}
Multivariate statistical techniques, principal component and cluster analysis were applied to the data on groundwater quality of Limestone aquifer in the southern region of Okinawa, Japan, to extract principal factors corresponding to the different sources of variation in the hydrochemistry, with the objective of defining the main controls on the hydrochemistry at the regional scale.

As a result of principal component analysis, ground water quality in the region could be classified into four principal components, that is, the groundwater is affected according to salt water and fertilizer (component 1), limestone dissolution (component 2), a redox state of a ground-water (component 3 ) and nitrogen accumulation/ denitrification (component 4). The cluster analysis was classified into four clusters according to the pollution situation of groundwater pollution in the study area, and the classification result was affected by season.
\end{abstract}

Key Words : groundwater, Ryukyu limestone, chemical composition, categories, multivariate analysis

\section{1.はじめに}

石灰岩帯水層は水資源として非常に有効であり，世界 の全人口の $25 \%$ の人々の飲料水を供給するなど1)，一部 の地域では, 唯一利用可能な飲料水あるいは農業用水の 貴重な水源となっている.

石灰岩帯水層の大きな特徵は, 鍾乳洞のような空洞や 大きな空隙が多数発達しており, 非常に不均一性が高い ことである.このような帯水層における地下水システム を把握するのは難しく, 石灰岩の複雑な地質構造の把握 や，各種トレーサーやモデリングを用いた総合的なアプ ローチが求められる21. 地下水中に溶存する化学物質を トレーサーに用いる手法は，ここ50年の間に，地下水シ ステムを理解するのに重要な役割を果たしてきだ4. な かでも, 主要イオンを用いた地下水水質の分類は非常に 一般的な方法となっており, 流動場や土地利用等の水理 化学的な側面から地下水水質を分類するのに有効である.

地下水水質の分類を容易にするため，へキサダイヤグ ラムやトリリニアダイヤグラムといった伝統的な手法に 加え, 多変量解析などの統計的分類手法が多く適用され
てきた ${ }^{5}$. 特に, 地下水位や主要イオン等の物理化学的 なデータを用いた主成分解析は, 地下水の水質の特徴を 把握するために広く用いられており, それらデータの短 期的あるいは特徵的な変動と自然や人為活動に起因寸る 季節変動特性とを結びつけるのに非常に有効である5 ${ }^{5)}$. 本研究の調査対象地域である沖縄本島南部地域（以下， 調査地域）は, 那覇市に近接する畑地農業地域であり, 古くから農業用水や生活用水として地下水が利用されて いる7)。調査地域では農業用水の確保を図るため, 糸満 市及び八重瀬町の1,352haの畑地を対象に国営沖縄本島 南部水利事業が実施され（1992年～2005年），米須と慶 座の2力所の地下ダムによって新たな水資源が開発され, 2006年から農業用水に地下水が利用されている8).

調査地域においていて先行研究9)がなされているが, 分析対象も調查地域に分布する湧水の夕で，対象とする 水質項目も硝酸性窒素にのみに重点が置か水ている. そ のため, 地下水の水質分類手法として一般的なへキサダ イヤグラムやトリニニアダイアグラム等を用いた水質分 


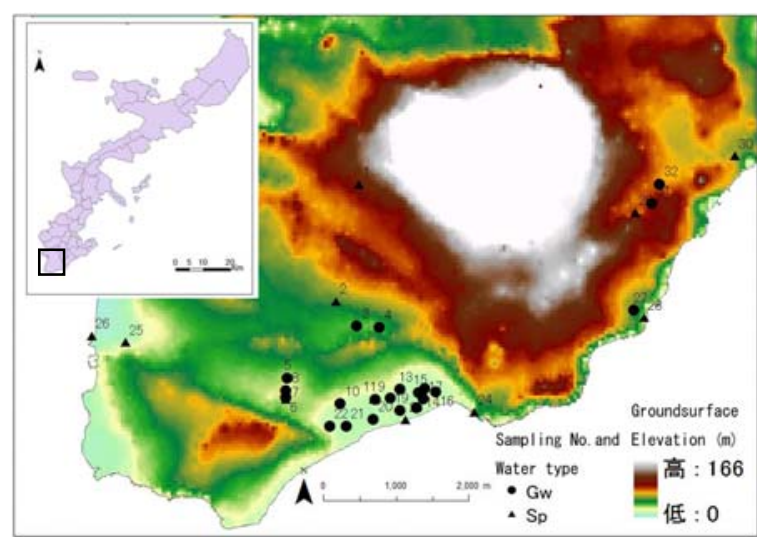

図-1 調査地域の状況と調査観測地点

類や，多変量解析などの統計的分類手法も適用されてお らず，調査地域の地下水水質特性に及ぼす自然や人為的 な影響を明らかにできているとはいえない。

以上の上うな状況を踏まえ，調査地域における今後の 水質管理を含めた地下水の適正な利用に資寸る観点から， 本研究では, 調查地域に分布する湧水と観測井戸を利用 した現地観測から得られた主要イオン等のデータに，主 成分分析等の多変量解析を適用し, 調查地域の地下水質 の統計的分類を実施すると共に，地下水水質への影響因 子を考察した.

\section{2. 調査研究概要}

\section{（1）調査地域}

調査地域は琉球石灰岩を表層地質とする段丘地形に よって特徴づけられ，河川の発達は見られず，地域内に は断層が縦横に発達し断層崖に沿って長く続くリッジ状 の丘が多く点在している. 調查地域には畑地（基幹作 物：サトウキビ）が広がり，その間に集落が塊状に点在 するとともに，農地利用が困難である断層崖付近に沿っ て森林が分布している（図-1）。また, 調査地域は新第 三紀鮮新世の島尻層群を基盤として, 第四紀更新世の琉 球層群が不整合に覆っているが，この島尻層群は砂岩・ 泥岩の互層からなる難透水性の地層である。一方，琉球 層群は隆起サンゴ礁や有孔虫を由来と寸る堆積岩で空隙 に富み極めて高い透水性を有しており, 琉球石灰岩と呼 ばれている. 地下水は難透水性地盤の島尻層群を受け典 として, 多孔質の琉球石灰岩中に腑存され，地下水盆を 形成している ${ }^{10)}$ 。調査地域の琉球石灰岩の層厚は最大 80m程度におよぶが，一般的に $20 \mathrm{~m} \sim 30 \mathrm{~m}$ が多い.

土地利用に関しては, 調查地域一面にはサトウキビ畑 が広がり，近年，電照菊等の花卉類の栽培も増えており， 一部に畜産施設もみられる。窒素負荷源の原単位や負荷 率の詳細は吉本 (2007) 9)をご参照いただきたいが，サ トウキビ畑では2.288 $\mathrm{kg} / \mathrm{m}^{2}$ とれている.

\section{（2）調査内容 $\cdot$ 方法}

本研究では, 図-1に示寸32地点（湧水：10力所, 民家 井戸：1カ所（ストレーナー位置G.L.-50m），観測井
表-1 測定項目と分析方法

\begin{tabular}{c|c}
\hline 水質項目 & 測定方法 \\
\hline $\begin{array}{c}\text { 水温, } \mathrm{pH}, \text { 電気伝導度 }(\mathrm{EC}) \\
\text { 酸化還元電位 }(\mathrm{ORP}), \text { 溶存酸素 }(\mathrm{DO})\end{array}$ & $\begin{array}{c}\text { 堀場製作所ポーダブル } \\
\mathrm{pH} \text { メータ D-54/D-55 }\end{array}$ \\
\hline $\begin{array}{c}\text { 陽イオン }\left(\mathrm{Na}^{+}, \mathrm{K}^{+}, \mathrm{Mg}^{2+}, \mathrm{Ca}^{2+}\right) \\
\text { 陰イオン }\left(\mathrm{Cl}, \mathrm{NO}_{3}^{-}-\mathrm{N}^{2}, \mathrm{SO}_{4}^{2-}\right)\end{array}$ & $\begin{array}{r}\text { イオンクロマトグラフ法 } \\
\text { (DIONEX ICS-1600) }\end{array}$ \\
\hline 重炭酸イオン $\left(\mathrm{HCO}_{3}^{-}\right)$ & アルカリ度適定法 \\
\hline
\end{tabular}

（基盤岩に到達するまで全面的にストレーナーを配 置）：21力所）ので採水を行った. 観測井における採水 深度は地下水面から-5m程度とした. 水質測定項目は, 水温, $\mathrm{pH}$, 電気伝導度 (EC), 酸化還元電位 $(\mathrm{ORP})$, 溶存酸素 (DO) , 陽イオン $\left(\mathrm{Na}^{+}, \mathrm{K}^{+}, \mathrm{Mg}^{2+}, \mathrm{Ca}^{2+}\right)$, 陰イオン $\left(\mathrm{Cl}^{-}, \mathrm{NO}_{3}^{-}-\mathrm{N}, \mathrm{SO}_{4}^{2-}\right)$, 重炭酸イオン $\left(\mathrm{HCO}_{3}^{-}\right)$である。 また，水質調査は，2011年9月から 2012年5月（2012年1月は除く）までの間において月1回 の頻度で実施しており, 測定項目・分析方法は表-1に示 すとおりである．なお，主成分分析とクラスター分析に よる水質特性の把握に際しては, エクセル統計アドイン ソフト2012を用いた。

\section{3. 結果と考察}

\section{（1）主成分分析による水質特性の把握}

地下水の, 水温, $\mathrm{pH}, \mathrm{EC}, \mathrm{ORP}, \mathrm{DO}$, 主要な溶存8 イオン成分を含めた 13 項目の水質情報に基づき, 調査 地域の水質特性を把握・評価する目的で主成分分析を 行った．なお，主成分分析に当たっては，32地点にお ける8回の調査より得られた水質サンプルを用いて相関 行列による解析を行った。 その際, 主成分の採用は固 有值1.0以上とした ${ }^{11)}$. 各主成分の寄与率を表-2に示す. 原データに対して，第4主成分までで累計寄与率 $74.5 \%$ が得られており, 調查地域の地下水水質は少数個の主 成分でその特性を集約できることが確認された.

そこで，主成分負荷量と水質情報の特性づけに先 立って, 各水質項目に対する負荷量の統計学的な有意 性を検証寸る観点から，負荷量の絶対值が概ね $20.3 \sim 0.6$ までの水質情報として第1主成分とDO（負荷量：0.461），第2主成分と $\mathrm{SO}_{4}^{2-}$ (負荷量：- 0.356），第4主 成分と $\mathrm{NO}_{3}^{-}-\mathrm{N}$ （負荷量：0.565）を選定して，その有意 水準について検討を加えた. 第1主成分と $\mathrm{DO}$, 第2主成 分と $\mathrm{SO}_{4}^{2-}$ ，及び第4主成分と $\mathrm{NO}_{3}^{-}-\mathrm{N}$ に係る $0.1 \%$ 有意水 準に対応するF值（11.09）の検定值として，それぞれ 66.05，35.58，115.04が得られおり，いずれも0.1\%以下 の水準で有意であるといえる. 主成分負荷量の絶対值 が0.3以上であれば0.1\%の有意水準を満たすことを踏ま え，有意性に係る統計学的な有意性について安全側を 確保する観点から, 主成分分析から得られた水質項目 のうち主成分負荷量の絶対值が 0.5 以上の水質情報につ いて評価の対象と寸る水質項目とした.

第1主成分は, $\mathrm{Na}^{+}, \mathrm{K}^{+}, \mathrm{Mg}^{2+}, \mathrm{Cl}^{-}, \mathrm{SO}_{4}^{2-}$ のイオン類 とECに係る主成分負荷量が 0.5 以上の正の值を示してい 
表-2 主成分分析の結果（主成分負荷量）

\begin{tabular}{|c|c|c|c|c|}
\hline 項目 & 第1主成分 & 第2 主成分 & 第3主成分 & 第4主成分 \\
\hline 水温 & 0.177 & -0.052 & -0.741 & -0.195 \\
\hline $\mathrm{pH}$ & -0.175 & 0.523 & 0.340 & -0.292 \\
\hline EC & 0.925 & 0.140 & -0.004 & 0.127 \\
\hline ORP & -0.147 & -0.217 & 0.764 & 0.026 \\
\hline $\mathrm{DO}$ & -0.461 & 0.159 & 0.173 & 0.590 \\
\hline $\mathrm{Na}^{+}$ & 0.895 & 0.299 & 0.091 & 0.155 \\
\hline $\mathrm{K}^{+}$ & 0.826 & 0.097 & 0.089 & -0.176 \\
\hline $\mathrm{Mg}^{2+}$ & 0.960 & 0.073 & 0.089 & -0.017 \\
\hline $\mathrm{Ca}^{2+}$ & 0.231 & -0.860 & -0.110 & -0.070 \\
\hline $\mathrm{Cl}^{-}$ & 0.882 & 0.297 & 0.082 & 0.187 \\
\hline $\mathrm{NO}_{3}^{-}-\mathrm{N}$ & 0.062 & -0.694 & -0.031 & 0.565 \\
\hline $\mathrm{SO}_{4}^{2}$ & 0.804 & -0.356 & 0.011 & 0.080 \\
\hline $\mathrm{HCO}_{3}^{-}$ & 0.281 & -0.602 & 0.329 & -0.464 \\
\hline 固有值 & 5.117 & 2.121 & 1.429 & 1.016 \\
\hline 寄与率 (\%) & 39.4 & 16.3 & 11.0 & 7.8 \\
\hline 累積寄与率（\%) & 39.4 & 55.7 & 66.7 & 74.5 \\
\hline
\end{tabular}

る. 第1主成分の主成分得点と $\mathrm{Na}^{+} \cdot \mathrm{Cl}$ 濃度の関係を検 討したところ，両者の間には正の相関（相関係数： 0.890，0.1\%有意水準に対応するF值（11.09）に対して 検定値は932.65であり，0.1\%以下の水準で有意）が存 在しており, 主成分得点は $\mathrm{Na}^{+} \cdot \mathrm{Cl}^{-}$濃度の上昇に対応 して高い值が得られることが確認された（図-3，図一 4）。また, $\mathrm{K}^{+}, \mathrm{Mg}^{2+}, \mathrm{SO}_{4}{ }^{2-}$ は主成分得点が増加するの に伴って高くなる傾向を示していることから，第1主成 分は，海水や海塩に由来する $\mathrm{Na}^{+}, \mathrm{Cl}^{-}$とともに，施肥 や生活排水に起因寸る $\mathrm{K}^{+}, \mathrm{Mg}^{2+}, \mathrm{SO}_{4}^{2-}$ が主な水質評価 指標となっていると考えられる，このように，第1主成 分は, 海水や海塩による自然現象に伴う影響とともに, 施肥や生活排水による人間の社会経済活動に伴う影響 を反映しており，地下水水質への外的影響要因を表す 主成分であるといえる.

また，第2主成分は，pHに係る主成分負荷量が 0.5 以 上の正の值を示寸一方で, $\mathrm{Ca}^{2+}, \mathrm{HCO}_{3}^{-}$, 及びNO ${ }_{3}^{-}-\mathrm{N}$ が - 0.5以下の負の值となっていることを踏まえ, 主成分 得点と $\mathrm{Ca}^{2+} \cdot \mathrm{HCO}_{3}$ 濃度の関係を検討したところ，両者 の間には負の相関（相関係数 : - 0.761，0.1\%有意水準 に対応するF値（11.09）に対して検定值は336.24であり, $0.1 \%$ 以下水準で有意）が存在しており, $\mathrm{Ca}^{2+} \cdot \mathrm{HCO}_{3}^{-}$ 濃度は第2主成分の主成分得点の值が高くなるに従って 低下している（図-5）。また, $\mathrm{Ca}^{2+}$ と $\mathrm{NO}_{3}^{-}-\mathrm{N}$ の間には 正の相関（相関係数 : 0.535）が存在（0.1\%有意水準に 対応寸るF值（11.09）に対して検定值は98.16であり, $0.1 \%$ 以下の水準で有意）しており，野村らが指摘して いるように窒素質化学肥料 (主に硫安) によって炭酸 塩の溶解促進が図られることから ${ }^{12)}$, 地下水の $\mathrm{NO}_{3}^{-}-\mathrm{N}$ 濃度には琉球石灰岩溶解に伴う影響が現れているもの と考えられる. $\mathrm{pH}$ の主成分得点は, 石灰岩の溶解に 伴う $\mathrm{Ca}^{2+} \cdot \mathrm{HCO}_{3}$ に対応して高い值を示すと考えられる ことから, 第2主成分は石灰岩溶解に由来又は影響され る $\mathrm{pH}, \mathrm{Ca}^{2+}, \mathrm{HCO}_{3}^{-}$, 及びNO ${ }_{3}^{-}-\mathrm{N}$ が主な水質評価指標 となっており, 地下水の流動・滞留に伴う石灰岩の溶 解現象を反映している主成分であると解釈される.

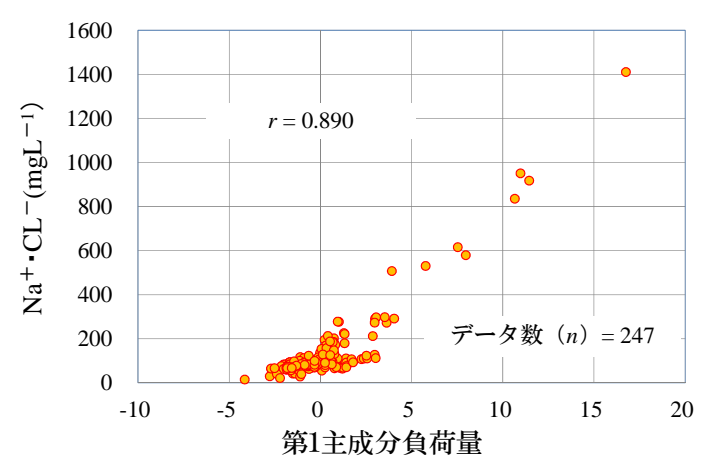

図-3 第1主成分得点と $\mathrm{Na}^{+} \cdot \mathrm{Cl}^{-}$の関係

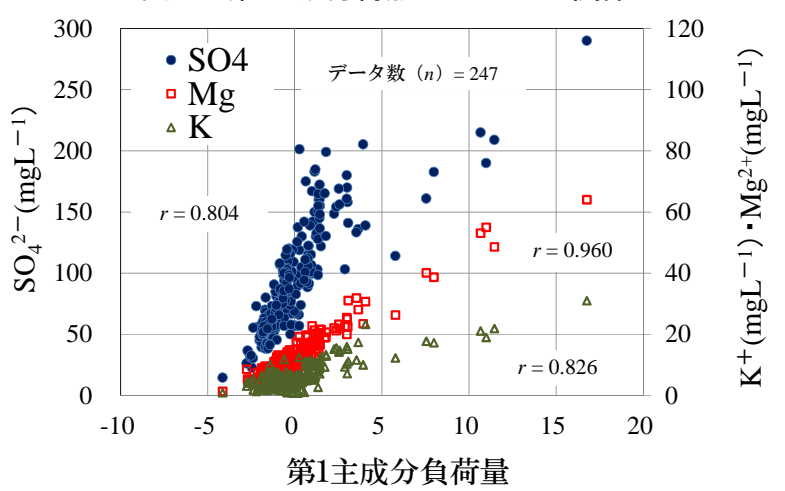

図-4 第1主成分得点と $\mathrm{Mg}^{2+} \cdot \mathrm{K}^{+} \cdot \mathrm{SO}_{4}{ }^{2-}$ の関係

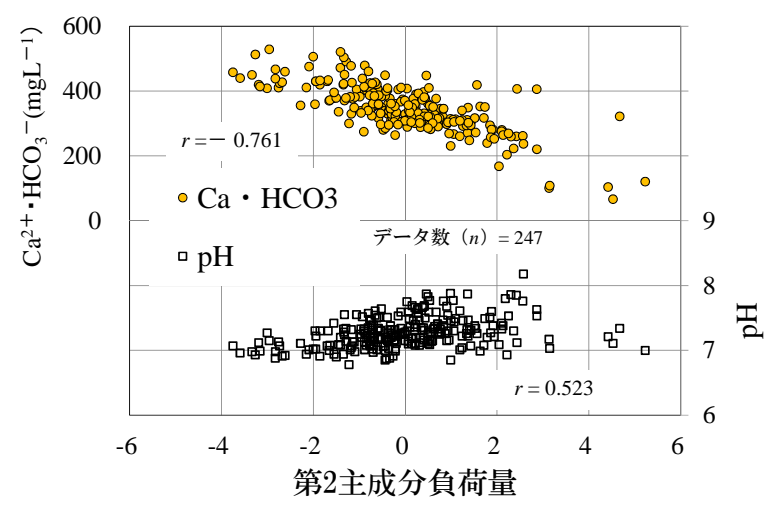

図-5 第2主成分得点と $\mathrm{Ca}^{2+} \cdot \mathrm{HCO}_{3}^{-} \cdot \mathrm{pH}$ の関係

一方，第 3 主成分は，ORPが 0.5 以上の正の值を示寸 とともに，水温が - 0.5以下の負の值となっていること から，水温や酸化還元状況を示寸ORPが主な水質評価 指標となっていると判断される. 第3主成分についても, 水理地質的条件に応じた酸化還元や地下水流動状況に よる影響を反映したもので，地下水水質への内的影響 要因をあらわす主成分であると考えられる．第4主成分

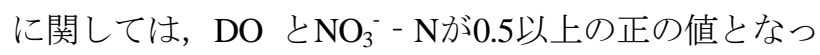
ており, 地下水中の溶存酸素々窒素成分の硝化状況を 表す水質評価指標となっていると解釈される. 第3・4 主成分についても, 水理地質的条件に応じた酸化還元/ 硝化・脱窒状況や地下水流動状況による影響を反映し た水質指標となっており，第2主成分と同じく地下水水 質への内的影響要因に係る主成分であると考えられる。

さらに，第1主成分に関与している水質情報のEC， $\mathrm{Na}^{+}, \mathrm{Cl}^{-}, \mathrm{K}^{+}, \mathrm{Mg}^{2+}, \mathrm{SO}_{4}{ }^{2-}$ は表-3に示すように対数正 
表-3 調査地域地下水の水質状況

\begin{tabular}{|c|c|c|c|c|}
\hline 項目 & 範囲 $*$ & 平均值* & 無次元化範囲 & 標淮偏差 \\
\hline 水温 & $20.9 \sim 26.3$ & 24.1 & $0.87 \sim 1.09$ & 0.04 \\
\hline $\mathrm{pH}$ & $5.8 \sim 8.2$ & 7.3 & $0.80 \sim 1.13$ & 0.03 \\
\hline EC & $0.501 \sim 3.110$ & 0.872 & $0.57 \sim 3.57$ & 0.38 \\
\hline ORP & $140.0 \sim 525.0$ & 232.6 & $0.60 \sim 2.26$ & 0.18 \\
\hline $\mathrm{DO}$ & $0.1 \sim 8.0$ & 3.8 & $0.03 \sim 2.09$ & 0.43 \\
\hline $\mathrm{Na}^{+}$ & $5.6 \sim 530.0$ & 47.8 & $0.12 \sim 11.09$ & 1.10 \\
\hline $\mathrm{K}^{+}$ & $0.8 \sim 31.0$ & 6.3 & $0.13 \sim 4.96$ & 0.67 \\
\hline $\mathrm{Mg}^{2+}$ & $1.4 \sim 64.0$ & 13.2 & $0.10 \sim 4.96$ & 0.60 \\
\hline $\mathrm{Ca}^{2+}$ & $19.0 \sim 170.0$ & 108.1 & $0.18 \sim 1.57$ & 0.23 \\
\hline $\mathrm{Cl}^{-}$ & $9.0 \sim 880.6$ & 72.4 & $0.13 \sim 12.16$ & 1.24 \\
\hline $\mathrm{NO}_{3}^{-}-\mathrm{N}$ & $0.4 \sim 22.9$ & 8.7 & $0.05 \sim 2.64$ & 0.43 \\
\hline $\mathrm{SO}_{4}^{2}$ & $14.6 \sim 290.0$ & 94.3 & $0.16 \sim 3.07$ & 0.45 \\
\hline $\mathrm{HCO}_{3}-$ & $47.5 \sim 378.0$ & 239.1 & $0.20 \sim 1.58$ & 0.23 \\
\hline \multirow{2}{*}{ 項目 } & \multicolumn{2}{|c|}{ 歪度 } & \multicolumn{2}{|c|}{ 尜度 } \\
\hline & 正規分布 & 対数正規分布 & 正規分布 & 対数正規分布 \\
\hline 水温 & -0.633 & -0.740 & 0.209 & 0.412 \\
\hline $\mathrm{pH}$ & -0.175 & -0.538 & 4.077 & 5.965 \\
\hline EC & 4.021 & 1.923 & 19.986 & 6.846 \\
\hline ORP & 1.342 & -0.002 & 9.196 & 1.598 \\
\hline $\mathrm{DO}$ & 0.120 & -2.032 & -0.444 & 7.456 \\
\hline $\mathrm{Na}^{+}$ & 5.678 & 1.775 & 39.094 & 6.580 \\
\hline $\mathrm{K}^{+}$ & 2.080 & -0.353 & 6.725 & 0.631 \\
\hline $\mathrm{Mg}^{2+}$ & 3.148 & 0.308 & 14.148 & 2.656 \\
\hline $\mathrm{Ca}^{2+}$ & 1.414 & -0.680 & 3.068 & 4.458 \\
\hline $\mathrm{Cl}^{-}$ & 5.696 & 1.686 & 38.685 & 5.985 \\
\hline $\mathrm{NO}_{3}-\mathrm{N}$ & 0.676 & -1.539 & 0.984 & 4.794 \\
\hline $\mathrm{SO}_{4}^{2-}$ & 1.006 & -0.312 & 1.487 & 0.401 \\
\hline $\mathrm{HCO}_{3}^{-}$ & -0.178 & -2.063 & 1.099 & 8.834 \\
\hline
\end{tabular}

注: *の欄の水温, $\mathrm{EC}, \mathrm{ORP}$ に係る単位はそれぞれ゚ $\mathrm{C}, \mathrm{mScm}^{-1}, \mathrm{mV}$ である とともに, DO と陽・陰イオン・重炭酸イオンの単位は $\mathrm{mgL}^{-1}$.

規分布に従った分布特性を示す一方で，第2・3・4主成 分に関わる水質項目は水温, $\mathrm{pH}, \mathrm{ORP}, \mathrm{DO}, \mathrm{Ca}^{2+}$, $\mathrm{HCO}_{3}^{-}, \mathrm{NO}_{3}^{-}-\mathrm{N}$ であるが, ORPとCa${ }^{2+}$ を除いてこれら の水質情報は対数正規分布に比べ正規分布に近い分布 特性となっている．第1主成分に関与する水質項目は, 第 $2 \cdot 3 \cdot 4$ 主成分に関わる水質項目に比較して広い範囲 に分布しており，右裾（大きな值）方向に伸びるよう な非対称な水質分布を示すことによるものと考えられ る. 第1主成分が海塩等の自然現象や人間の社会経済活 動に伴う地下水水質への外的影響を反映したものであ るのに対して，第2・3・4主成分は地下水流動に伴う石 死岩溶解現象や酸化還元/硝化・脱窒状況等の水理地質 構造による地下水水質への内的影響をあらわしている ことも，両者に水質分布特性の相違を生じさせている 要因の一つであると推察される.

以上のことから, 琉球石灰分布地域においては，i） 海水や海塩による自然現象，施肥や生活排水による人 間の社会経済活動， ii）地下水の流動・滞留に伴う石 死岩の溶解現象，iii）水理地質的条件に応じた酸化還 元状態，iv）硝酸性窒素の集積・脱窒状況を指標にす る4つの主成分で水質の特性づけと評価を行えることが 明らかになった。

\section{（2）クラスター分析による地下水水質の類型化}

地下水水質の類型化を図るため，32調査地点について
表-4 クラスター別の平均濃度

\begin{tabular}{ccccc}
\hline クラスター & 1 & 2 & 3 & 4 \\
\hline 水温 & 24.0 & 24.1 & 24.4 & 24.6 \\
$\mathrm{pH}$ & 7.3 & 7.2 & 7.3 & 7.2 \\
$\mathrm{EC}$ & 0.712 & 0.899 & 2.620 & 2.006 \\
$\mathrm{ORP}$ & 221.8 & 241.6 & 211.6 & 199.0 \\
$\mathrm{DO}$ & 4.5 & 3.5 & 1.6 & 2.0 \\
$\mathrm{Na}^{+}$ & 31.0 & 45.2 & 381.3 & 205.8 \\
$\mathrm{~K}^{+}$ & 4.7 & 6.6 & 23.3 & 14.3 \\
$\mathrm{Mg}^{2+}$ & 9.0 & 14.3 & 55.2 & 32.1 \\
$\mathrm{Ca}^{2+}$ & 93.8 & 118.4 & 106.5 & 82.3 \\
$\mathrm{Cl}^{-1}$ & 45.2 & 66.6 & 646.8 & 351.8 \\
$\mathrm{NO}_{3}-\mathrm{N}$ & 7.7 & 9.4 & 9.3 & 4.9 \\
$\mathrm{SO}_{4}{ }^{-}$ & 64.8 & 108.3 & 226.0 & 165.8 \\
$\mathrm{HCO}_{3}{ }^{-}$ & 198.3 & 266.9 & 274.8 & 206.9 \\
\hline
\end{tabular}

表-5 クラスター別の第1４主成分の主成分得点

\begin{tabular}{c|cccc}
\hline クラスター & 1 & 2 & 3 & 4 \\
\hline 主成分 1 & $-4.14 \sim 0.39$ & $-1.95 \sim 4.05$ & $10.66 \sim 16.76$ & $3.93 \sim 7.98$ \\
主成分 2 & $-1.17 \sim 4.53$ & $-3.75 \sim 1.86$ & $0.235 \sim 4.67$ & $1.56 \sim 5.23$ \\
主成分 3 & $-2.17 \sim 2.19$ & $-2.25 \sim 4.44$ & $0.53 \sim 2.04$ & $-2.07 \sim 1.52$ \\
主成分 4 & $-1.79 \sim 1.90$ & $-3.66 \sim 2.42$ & $-0.46 \sim 2.75$ & $-0.66 \sim 1.66$ \\
\hline
\end{tabular}

調査観測毎（データ数247）にウオード法によるクラス ター分析を試みた。まず，同データを用いてクラスター 数として4から7に設定してその規模を検討したところ, クラスター数の増加に対応してクラスター分類は細分化 されることになるが，クラスター数を5以上とすると データ規模数4のクラスターが生じることになる. 1クラ スターの規模があまり小さくなることを避け，調査地点 の水質特性を単純化して類型化する観点から, 本研究に おいてはクラスター数を4に設定し地下水水質の類型化 を行った. クラスター別の平均濃度を表-4にまとめると ともに，第1～4主成分の主成分得点を表-5に示した.

クラスター1においては第1主成分に係る得点が - 4.14 〜0.34（平均得点：-1.31）を示しているとともに，第2 主成分の主成分得点が - 1.17〜 4.53（平均得点 : 0.87) の範囲となっている. 第3主成分と第4主成分の主成分得 点はそれぞれ - 2.17〜2.19（平均得点：-0.24），- 1.79 〜 1.90 (平均得点 : 0.21) の領域に存在している. また,

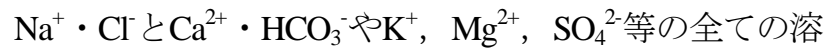
存イオン濃度の平均值が他のクラスターに比較して低い ことなどを踏まえると, クラスター 1 は海水・海塩や施 肥・生活排水等の社会経済活動による影響が少なく, 石 灰岩の溶解現象と硝酸性窒素による污染も進んでいない ものと考えられる. 一方，クラスター3は第1主成分の得 点が10以上の值（10.66～16.76）を示しているとともに, $\mathrm{Na}^{+} \cdot \mathrm{Cl}^{-}$と $\mathrm{K}^{+}, \mathrm{Mg}^{2+}, \mathrm{SO}_{4}^{2-}$ の平均濃度が他のクラスター に比べて著しく高くなっている. クラスター3の第2主成 分得点は0.23〜4.67（平均得点：2.55）と正の領域に存 在しており, $\mathrm{Ca}^{2+}$ と $\mathrm{HCO}_{3}$ 濃度はクラスター 1 に比べて高 い濃度水準を示している. 第3，4主成分得点はそれぞれ $0.53 \sim 2.04$ （平均得点：1.16），- 0.46〜2.75（平均得 
表-6 調査観測のクラスター解析による類型化

\begin{tabular}{|c|c|c|c|c|c|c|c|c|c|}
\hline $\begin{array}{l}\text { 観測 } \\
\text { 地点 } \\
\end{array}$ & $\begin{array}{l}2011 \\
9 \text { 月 } \\
\end{array}$ & 10 月 & 11月 & 12月 & $\begin{array}{l}2012 \\
2 \text { 月 } \\
\end{array}$ & 3月 & 4月 & 5月 & $\begin{array}{l}\text { 分類 } \\
\text { 結果 }\end{array}$ \\
\hline 1 & 1 & 1 & 1 & 1 & 1 & 1 & 1 & 1 & 1 \\
\hline 2 & & 1 & 1 & 1 & 1 & 1 & 1 & 1 & 1 \\
\hline 3 & 2 & 2 & 1 & 2 & 2 & 2 & 1 & 1 & $1 / 2$ \\
\hline 4 & 2 & 2 & 2 & 2 & 2 & 2 & 2 & 2 & 2 \\
\hline 5 & 2 & 2 & 2 & 2 & 2 & 2 & 2 & 2 & 2 \\
\hline 6 & & 2 & 2 & 2 & 1 & 1 & 1 & 1 & $1 / 2$ \\
\hline 7 & 1 & 2 & 2 & 2 & 2 & 1 & 2 & 2 & $1 / 2$ \\
\hline 8 & 2 & 2 & 1 & 2 & 2 & 2 & 2 & 2 & $1 / 2$ \\
\hline 9 & 1 & 1 & 1 & 1 & 1 & 1 & 1 & 1 & 1 \\
\hline 10 & & 2 & 2 & 2 & 2 & 2 & 1 & 2 & $1 / 2$ \\
\hline 11 & 1 & 1 & 1 & 1 & 1 & 1 & 1 & 1 & 1 \\
\hline 12 & 2 & & & 2 & 1 & 2 & 1 & 1 & $1 / 2$ \\
\hline 13 & 2 & 2 & 1 & 2 & 2 & 2 & 1 & 1 & $1 / 2$ \\
\hline 14 & 2 & 2 & 2 & 2 & 2 & 2 & 1 & 1 & $1 / 2$ \\
\hline 15 & 2 & & 1 & 2 & 2 & 2 & 2 & 2 & $1 / 2$ \\
\hline 16 & 2 & 2 & 2 & 2 & 2 & 2 & 2 & 2 & 2 \\
\hline 17 & 2 & 2 & 1 & 1 & 1 & 2 & 2 & 1 & $1 / 2$ \\
\hline 18 & 2 & 2 & 1 & 2 & 2 & 2 & 1 & 2 & $1 / 2$ \\
\hline 19 & 2 & 2 & 1 & 1 & 2 & 2 & 1 & & $1 / 2$ \\
\hline 20 & 2 & 2 & & 2 & 2 & 4 & 1 & 2 & $1 / 2 / 4$ \\
\hline 21 & 3 & 3 & 3 & 4 & 2 & 2 & 4 & 4 & $2 / 3 / 4$ \\
\hline 22 & 2 & 2 & 2 & 2 & 2 & 2 & 2 & 2 & 2 \\
\hline 23 & 2 & 2 & 2 & 2 & 2 & 1 & 1 & 1 & $1 / 2$ \\
\hline 24 & 2 & 2 & 2 & 2 & 2 & 2 & 1 & 1 & $1 / 2$ \\
\hline 25 & 1 & 2 & & 2 & 2 & 1 & 1 & 1 & $1 / 2$ \\
\hline 26 & 3 & 2 & & 2 & 2 & 2 & 1 & 2 & $1 / 2 / 3$ \\
\hline 27 & 1 & 2 & 2 & 2 & 1 & 1 & 1 & 2 & $1 / 2$ \\
\hline 28 & 2 & 2 & 2 & 2 & 1 & 1 & 1 & 1 & $1 / 2$ \\
\hline 29 & 1 & 2 & 2 & 2 & 1 & 1 & 1 & 1 & $1 / 2$ \\
\hline 30 & 1 & 2 & 2 & 2 & 1 & 1 & 1 & 1 & $1 / 2$ \\
\hline 31 & 1 & 2 & 2 & 2 & 1 & 1 & 1 & 1 & $1 / 2$ \\
\hline 32 & 2 & 2 & 2 & 2 & 1 & 2 & 1 & 2 & $1 / 2$ \\
\hline
\end{tabular}

注 : 各観測地点の月毎のクラスター解析による分類值. 分類結果では地点 毎の代表的な類型值を表示

点：1.30）が得られており，DO濃度は低い值を示して いるとともに, $\mathrm{NO}_{3}^{-}-\mathrm{N}$ 濃度はクラスター1に比較しての 高い濃度水準となっている. このように，クラスター3 は嫌気的条件下にある一方，海水・海塩や施肥・生活排 水等の社会経済活動に強く影響されているクラスターで あると判断される.

また，クラスター4は第1主成分と第2主成分に係る得 点がそれぞれ3.93〜 7.98（平均得点：6.30），1.56～5.23

(平均得点 : 2.04）の範囲となっており, $\mathrm{Ca}^{2+}$ と $\mathrm{NO}_{3}-\mathrm{N}$ 以外の溶存イオン濃度 $\left(\mathrm{Na}^{+} \cdot \mathrm{Cl}^{-}, \mathrm{HCO}_{3}^{-}, \mathrm{K}^{+}, \mathrm{Mg}^{2+}\right.$, $\left.\mathrm{SO}_{4}^{2-}\right)$ の平均值はクラスター 1 とクラスター 3 の中間的な 值が得られている．第3主成分と第4主成分の主成分得点 は概ね - 4〜2の領域（第3主成分：-4.33〜1.88, 第4主 成分：- 3.52〜2.07） に分布しているとともに, DOと $\mathrm{NO}_{3}{ }^{-}-\mathrm{N}$ 濃度が他のクラスターに比較して最も低い值が得 られていことからも, クラスター4は海水・海塩と施 肥・生活排水等の社会経済活動による影響に関してはク ラスター 1 と 3 中間的な特徵を示す一方で，嫌気的条件 下にあり脱窒の可能性のあるクラスターと推察される.

さらに，クラスター2は第1主成分と第2主成分の主成 分得点がそれぞれ-1.95〜4.05（平均得点：0.35）， 3.75〜1.86（平均得点：- 0.73）の範囲となっており,

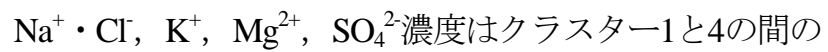

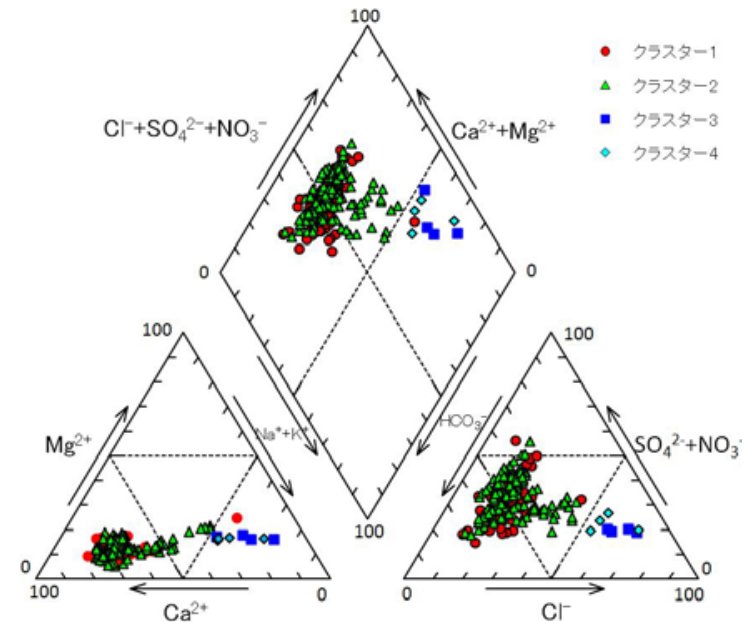

図-6＼cjkstart調査地域水質のトリリニヤダイアグラム

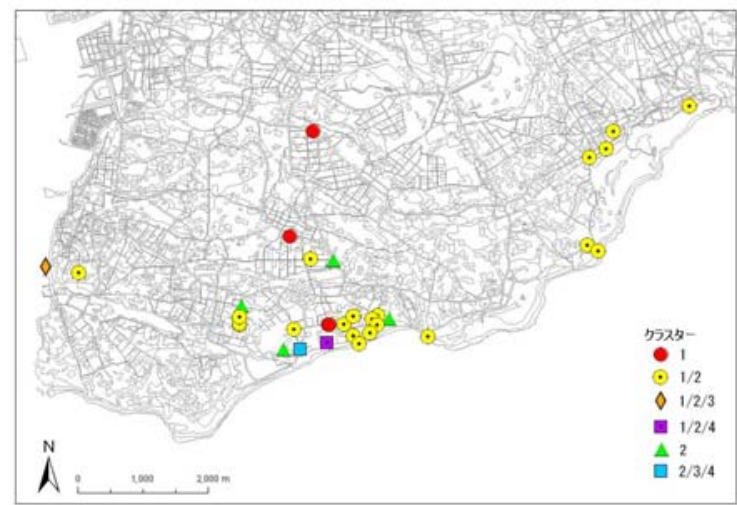

図-7 調査地域水質の平面分布

值であるとともに, $\mathrm{Ca}^{2+}$ と $\mathrm{HCO}_{3}{ }^{-}$はクラスター3と同じよ うに高い濃度水準を示している．第3主成分と第4主成分 に係る得点はそれぞれ-2.25～4.43（平均得点：0.14）， - 3.66〜2.42（平均得点：- 0.19）であり, $\mathrm{NO}_{3}^{-}-\mathrm{N}$ 濃度 はクラスター3と同じように高い值が得られる.これら のクラスター解析の結果を踏まえると, クラスター 2 は 海水・海塩と施肥・生活排水等の社会経済活動による影 響をクラスター 1 よりも強く受けているとともに，硝酸 性窒素の集積も進んだクラスターであると考えられる.

その一方で, クラスター2は石灰岩の溶解による影響が クラスター3と同じように強く現れているクラスターで あるといえる.

調査地点のうち概ね半数は調査期間を通じてほぼ同じ クラスターに分類される一方で，残りの大半の地点では 調査時期に応じてそのクラスター分類が異なっているこ とが確認された（表-6）。このことから，調査地域の地 下水水質については，調査地点によって時期的な影響を 受けずに地理的な要因による地点と, その一方で地理的 な影響とともに時期的・季節的な影響に左右されている 地点があることが明らかになった。このため, トリリニ ヤアダイアグラムより, クラスター分類に従って調査地 域の地下水を評価したところ，クラスター1と2のほとん どが炭酸塩硬度型と中間型の領域に幅広く分布するとと もに，クラスター3と4はアルカリ非炭酸塩型に属してい 
ることが確認された（図-6）。調査地域の水質は, 図-7 に示寸ような平面分布となっており，上流域から下流域 に向かって海水・海塩や施肥・生活排水等の社会経済活 動と石灰岩溶解による影響に伴って, クラスター分類が 1から3・4几と移行する傾向が認められるものの, 地理 的に複雑な空間分布特性を有している. 既往の調查成果 によると，調査地域には多くの断層や鍾乳洞等に関連す る琉球石灰岩の溶解亀裂部が存在し, 琉球石灰岩分布地 域帯水層の不均一地盤に起因寸る水理地質構造が影響を 与えており，このことが地下水の空間分布特性に反映さ れているものと考えられる. 今後, 調查地域地下水の現 場水質観測データの蓄積・把握や琉球石灰岩分布地域帯 水層特有の不均一地盤水理地質構造を対象とした数值解 析等を通じて, 地下水の水質組成形成メカニズムについ てさらに定量的に考察したいと考えている.

\section{4. まとめ}

本研究は, 琉球石灰岩分布域である沖縄本島南部地 域の地下水水質を多変量解析を用いて統計的に分類し たものであり,得られた検討結果は以下のとおりである。

(1)調查地域の地下水は, 炭酸水素カルシウム (Ca$\left.\mathrm{HCO}_{3}\right)$ 型の特徴を示し, 海岸近くでは塩化ナトリウム

（Na-Cl）型を呈する調查地点もあり，地下水水質への 海水・海塩による影響が示唆された.

(2)主成分分析の結果，調査地域の地下水水質は第4主 成分まででその特性の74.5\%を集約できるとともに，i ） 海水や海塩による自然現象, 施肥や生活排水による人 間の社会経済活動，ii）地下水の流動・滞留に伴う石 灰岩の溶解現象，iii）水理地質的条件に応じた酸化還 元状態，iv）硝酸性窒素の集積・脱窒状況を指標にす る4つの主成分で水質の特性づけと評価を行えることが 明らかになった。

(3)第1主成分は海塩等の自然現象や人間の社会経済活 動に伴う地下水水質への外的影響, 第 $2 \cdot 3 \cdot 4$ 主成分は 地下水流動に伴う石灰岩溶解現象や酸化還元/硝化・脱 窒状況等の水理地質構造による地下水水質への内的影 響を捉えており，このことが両者に関与する水質情報 の分布特性に相違を生じさせていると推察される.

(4)クラスター分析の結果, 調査地域の地下水水質は, i ）海水・海塩や施肥・生活排水等の社会経済活動に よる影響が少なく, 石灰岩の溶解現象と硝酸性窒素に よる污染が進んでいないクラスター，ii）海水・海塩 と施肥・生活排水等の社会経济活動による影響が少し 進み, 石灰岩の溶解による影響が強いクラスター, iii） 海水・海塩と施肥・生活排水等の社会経済活動による 水質污染がある程度進行しているクラスター, iv）脱 窒が行われている一方, 海水・海塩や施肥・生活排水 等の社会経済活動に強く影響されているクラスターに 分類することができた.
(5)調查地域の地下水水質は, 地理的条件のみで時間 的な影響を受けていない地点と, その一方で地理的な 影響とともに時期的・季節的な影響に左右されている 地点があることが確認された。 また，上流域から下流 域に向かって海水・海塩や施肥・生活排水等の社会経 済活動と石灰岩溶解による影響に伴って溶存イオン濃 度が増加する傾向が認められるものの, 地理的に複雑 な空間分布特性を有している. 調查地域には多くの断 層や鍾乳洞等に関連する琉球石灰岩の溶解亀裂部が存 在し, 琉球石灰岩分布地域帯水層の不均一地盤に起因 する水理地質構造が地下水水質の時期的・地理的な変 動特性に影響を与えているものと推察される.

\section{謝辞}

本研究の遂行にあたり, 内閣府沖縄総合事務局土地改 良総合事務所, 沖縄県南部農林土木事務所, 沖縄本島南 部土地改良区の関係各位に多大の御援助と御協力を頂い たことを記し, 深甚の感謝を表します。

\section{参考文献}

1) Ford DC, Williams PW.: Karst geomorphology and hydrology, Springer; 1 edition, 1989.

2) Bakalowicz, M: Karst groundwater: a challenge for new resources. Hydrogeology Journal, 13(1), pp.148-160, 2005.

3) Glynn, PD, Plummer, LN.: Geochemistry and the understanding of groundwater system. Hydrogeology Journal, 13, pp.263-287, 2005.

4) Guler, C, Thyne, GD, McCray, JE, Turner, K: Evaluation of graphical and multivariate statistical methods for classification of water chemistry data, Hydrogeology Journal, 10, pp.455-474, 2002.

5) Bakalowicz, M: Water geochemistry: water quality and dynamics. In: Stanford J, Gilbert J, Danielopol D (eds): Groundwater ecology., Academic Press, pp.97-127, 1994.

6) Helena, B, Pardo, R, Vega, M, Barrado, E, Fernandez, JM, Fernandez, L: Temporal evolution of groundwater composition in an alluvial aquifer (Pisuerga River, Spain) by principal component analysis, Water Research, 34(3), pp.807-816, 2000.

7) 沖縄総合事務局本島南部農業水利事業所: 沖縄本島南部農業水利事 業一技術誌一,pp.7-12, 2006.

8) 名和規夫, 青木進, 中尾仁: 沖縄本島南部地区における地下ダムの 役割と効果,農業土木学会誌, 74（12）, pp.33-36, 2006.

9) 吉本周平, 土原健雄, 石田聡, 今泉眞之: 米須地下ダム流域における 地下水硝酸性窒素濃度の動態について, 農村工学研究所技報, 206, pp.195 208, 2007.

10) 木崎甲子郎: 琉球弧の地質誌, 沖縄タイムズ社, pp.287, 1985

11) 田中豊, 垂水共之, 脇本和昌: パソコン統計解析ハンドブック II多 変量解析編, 共立出版, pp.160-175, 1984.

12) 野村渉平, 入江満美，牛久保明邦，中西康博: 宮古島の湧水口にお ける大気中 $\mathrm{CO}_{2}$ 濃度と地下水水質との関係, 日本土壌肥料学雑誌, 82, pp.275-282, 2011.

(2012. 9. 30 受付) 